\title{
Toward a Transnational Methodology: Methods to Address Methodological Nationalism, Essentialism, and Positionality
}

Vers une méthodologie transnationale: méthodes pour aborder le nationalisme méthodologique, l'essentialisme et le positionnement

Hacia un método transnacional: métodos para abordar el nacionalismo metodológico, la esencialidad del objeto y el posicionamiento del investigador

\section{Thomas Faist}

\section{(2) OpenEdition}

\section{Journals}

Electronic version

URL: https://journals.openedition.org/remi/5761

DOI: $10.4000 /$ remi.5761

ISSN: $1777-5418$

\section{Publisher}

Université de Poitiers

\section{Printed version}

Date of publication: 1 March 2012

Number of pages: $51-70$

ISBN: 979-10-90426-03-0

ISSN: 0765-0752

\section{Electronic reference}

Thomas Faist, "Toward a Transnational Methodology: Methods to Address Methodological

Nationalism, Essentialism, and Positionality", Revue européenne des migrations internationales [Online], vol. 28 - $n^{\circ} 1$ | 2012, Online since 01 March 2015, connection on 14 April 2022. URL: http:// journals.openedition.org/remi/5761 ; DOI: https://doi.org/10.4000/remi.5761 


\section{Toward a Transnational Methodology: Methods to Address Methodological Nationalism, Essentialism, and Positionality}

\section{Thomas FAIST ${ }^{1}$}

Using sually methodology is discussed in relation to a particular discipline or an established field of research. Here it is the latter, the field of transnational studies. This consideration of methodology is important for understanding the methods that have been used to arrive in a systematic way at substantive results regarding topics of interest in transnational studies, such as the meaning of transnational ties and practices for life-chances; the genesis and reproduction of cross-border social spaces; the implications of transnationalization for what is called development in the countries of emigration and immigration; the social integration of persons, that is, immigrant incorporation; the changing political practices, membership and public policies of the states involved. In short, methodology connotes a set of procedures or methods used to conduct research. It provides a systematic basis for deciding which methods are likely to provide the types of knowledge needed to answer specific research questions.

Before delving into the methodological concerns raised by transnational studies, a note on terminology is necessary. In order to avoid the diffuse catch-all term transnationalism, three more specific concepts are used - transnationalization, transnational social spaces and transnationality (see Faist et al., 2012). Transnationalization or transnational relations implies cross-border ties of individual and collective agents, such as migrants, migrant associations, multinational companies, religious communities, which constitute a social category. Transnational social spaces refer to sustained concatenation of crossborder ties and social practices, as exemplified, for example, in cross-border families, networks (e.g. networks of non-governmental organizations, issue networks and networks of business people), transnational communities and organizations. Transnationality denotes a continuum of trans-state ties and practices, ranging from less to more intense

1 University Professor of Sociology, Centre on Migration, Citizenship and Development(COMCAD), Bielefeld University, P.O. Box 100131, D-33501 Bielefeld; thomas.faist@uni-bielefeld.de 
and regular. Agents' transnational ties constitute a marker of heterogeneity, akin to other heterogeneities, such as age, gender, citizenship, sexual orientation, cultural preferences or language use. Transnational ties can be understood as occupying a continuum from low (very few and unsustained ties across borders) to high (multiple and dense ties and continuous over time). This is also to say that migrants and non-migrants should not simply be considered as transnational or not, but as being potentially transnational to different degrees. In the case of cross-border processes, transnationality, and not just well-known heterogeneities such as ethnicity or gender, is thus one of several potential heterogeneities of persons and groups.

\section{THREE METHODOLOGICAL CHALLENGES FOR TRANSNATIONAL STUDIES}

There are three methodological challenges for contemporary migration studies in general and for transnational research in particular (see also Amelina et al., 2012a and 2012b for more extended expositions).

First, immigration researchers too often presume the national state to be the (only) central relevant context for empirical studies on international migration, as if the state were a container. State and society are sometimes held to be coterminous and territorially identical. There is the assumption of a congruence of societal practices and nation-states and the collection of data within the confines of national states. In general, methodological nationalism in the social sciences marks the tendency to treat the container of the national state as a quasi-natural social and political configuration (Martins, 1974). Therefore, we carefully need to re-define the unit of analysis. One rule of thumb is to be very precise as to the scope of empirical analysis and reference to the respective collective. While the state could be a unit of analysis (e.g. in public policies relating to the diaspora), other units of analysis are possible, depending on the research question, e.g. kinship groups, local communities or organizations.

Second, quite often ethnicity or nationality is unquestioningly used as the dominant category relevant for research organization, and sometimes ethnic or national belonging is even naturalized, that is, migrants are seen above all as members of an ethnic group - e.g. Turks or Mexicans or Filippinos - and their roles as workers, professionals, parents, children, lovers, and members of associations or local communities are not considered sufficiently. Thus an essentialist approach treats groups as quasi-homogeneous and does not consider the internal heterogeneity of migrant categories. It thus reproduces the primacy of the national or ethnic lens.

Third, transnational studies raise in a very urgent and obvious way the issue of the positionality of the researchers. This is pertinent, for example, if research is carried out across states and researchers from countries of emigration and immigration collaborate. Problems arise over the asymmetry of control over funds and social scientific concepts. For example, it is mostly researchers from immigration states who control the funding and are funded by their home states or supranational organizations such as the European Union. 
This puts researchers from states of origin - mostly non-OECD and non-EU countries - at a severe disadvantage (Faist, 2004a: 30-32).

We now need to define in more detail these three methodological challenges for transnational research, to indicate the elements of these problems, and to present methodological tools, to be followed by an overview of selected methods used to tackle these three challenges and to analyse transnational practices and cross-border social formations. The methods discussed include multi-sited ethnography, that is, fieldwork in various sites and places across countries; mobile ethnography, that is, the research conducted by the researcher en route, following the migrants; the extended case study method in which theoretical assumptions are defined from the start and followed by empirical work; network methodology, which helps to locate cross-border ties of persons and collectives but also identifies virtual networks on the web; and, finally, quantitative surveys and longitudinal (panel) studies. Of these methods, scholars working with a transnational lens in the field of migration have most often used multi-sited ethnography. Scholars have less often used the extended case study method, quantitative surveys and network methodology, and rarely used mobile ethnography (a very recent method) and longitudinal studies (because of the high costs in terms of time and funds).

\section{The Challenge of Methodological Nationalism}

Methodological nationalism assumes that national state institutions are the main social context within which migration occurs and for which migration is relevant. Primary examples of this assumption can be found above all in studies on migration control and social integration of immigrants. Most of them deal with immigration regulation and immigrant incorporation in a single national state; at most, they are comparative in nature and thus compare regulations and social processes in various nation states. Consequently, the organization of empirical research is limited to the territorial 'container' of a national state, usually an immigration one. We find this 'container' thinking not only in older assimilation theories (Gordon, 1964), but also in sophisticated concepts of multiculturalism. In a nutshell, most past research has presupposed unquestioningly the congruence of society, the institutional arrangements of the national state and the related territorial framework; in other words, of the people, state authority and territory (Faist, 2004b: 331-332). Various authors have outlined the negative consequences of 'methodological nationalism' in migration studies (Wimmer and Glick Schiller, 2003). Wimmer and Glick Schiller, in particular, differentiate three types of methodological nationalism. First, they argue that mainstream migration studies do not pay attention to nationalism and its effects on nationbuilding processes. According to the authors, sociology defines 'the limits of society as coterminous with the nation state, rarely questioning nationalist ideology embedded in such a founding assumption' (2003: 579). One pertinent example running against such an assumption is the effort of nationalist diasporas to establish a national state of their own, in the past directed against multi-national empires, such as the Austro-Hungarian or the Russian Empire, or today against national states, as in the case of Tamils or Palestinians. This is an instance of how nationalism as an ideology is guiding the practices of collective actors. Second, Wimmer and Glick Schiller criticize an understanding of nation states as quasi-natural entities that neglects how nation states structure social relations. Such 
an understanding leads to a close coupling between national state authorities and social science, not only by funding programs that support migration research, which are often governmental, but also by research which occludes all non-sedentary parts of the population. In quantitative research, for example, this has the effect of omitting from the picture individuals who are mobile, such as seasonal workers or undocumented migrants. Third, they argue that empirical social research focuses primarily on the territorial boundaries of national states. But the 'territorial limitation' of power relations is a historically new phenomenon that emerged in the process of national state establishment, whereby the latter itself was determined by cross-border power dynamics and activities. As a consequence, there has been a mismatch between cross-border phenomena on the one hand and the collection of statistics on the other hand: "The subject matter of international migration is cross-national in scope, whilst international migration statistics are the products of national government ministries, administrations and statistical institutes." (Singleton, 1999: 156)

In sum, a double gap - the national state as the main social context of migration as well as the territorial framework of empirical migration studies - determines strategies of research design as well as methods of data collection and analysis (e.g. Bonifazi et al., 2008). Of course, this is not to argue that national states are not important for analysis. For specific research objectives, a focus on the nexus between state authority and territory is helpful, for example, in understanding immigration control. Over the past decades many immigration states have stepped up the efficiency of migration control and thus control over migrants (Faist and Ette, 2007). Yet a sole emphasis on this congruence is inadequate if researchers are to understand how transnational social spaces emerge and are reproduced, and the practices of migrants and non-migrants involved. To emphasize, the critique of methodological nationalism should not lead to discarding the role of the national state. The main point is not data collection on the national level but the missing situatedness of the national-state level. When analyzing immigrant incorporation, it is necessary also to consider the cross-border ties and practices of persons. Therefore, it would be premature to simply replace the national state as the main unit of analysis with household, city or even the world or globe.

Various alternatives to the national state as the quasi-natural unit of analysis have been proposed. Most prominently, these have been the global network approach and world theories. Yet these also suffer from a major defect in that they peremptorily and in advance define a primary unit of analysis. The first of these privileges cross-border networks. The network approach to globalization (Castells, 1996) describes and explains why and how social life has become "disconnected" from territorial limitations in general and from national state territories in particular. This view does not claim that society is congruent with the national state or national state territories and institutions. It holds that society is made up of social networks criss-crossing the globe. The second position, the world theories, which includes the world systems (Wallerstein, 1974) approach, conceptualizes the globe as encompassed in a single over-arching system. Despite significant differences between them, for example relating to the role of the national state, both perspectives take a bird's-eye view, from the top down. They also hold that the world view is a privileged vantage point. In particular, while the network approach eschews fixed categorizations and stresses the novelty of hybridity in a world of constant motion, it leaves unchallenged 
the notion that in the past ethnic and national identities were fixed. In overgeneralizing de-territorialization, it overlooks processes of spatialized capital accumulation (Massey, 2008) as well as global restructuring of social spaces along the intensity, density and velocity of flows (Held et al., 1999). World theories, in turn, have sophisticated views of the national state. In world systems theory, for example, states are crucial elements making up the centre, periphery and semi-periphery of a tiered political-economic global system. In this view, states run counter to the main elements of societal (sub)systems of politics, economics and culture. Although these world theories reflect on nation-building as a historically specific process, they predominantly view spatiality and geographic mobility as unchanging physical property that need not be the concern of social theory and methodology.

To deal with the problem of contextualizing migration and thus the unit of analysis, a transnational approach proposes to identify the national state as one of several possible social frameworks in which to situate empirical studies. For alternative social contexts to the national state, transnational social space is an available conceptual tool which can serve as a point of departure for moving beyond methodological nationalism. This requires scholars to reflect upon spatial concepts which are often implicitly applied in empirical analyses. We cannot assume the congruence of social life on the one hand and the territory of the nation state on the other. In contrast, we could assign to the respective social context a relationally organized spatial framework in looking at ties and practices; of which, as is evident, national states are an integral part, although only one of several possible elements. National states, for example, control access to the territory by regulating flows across borders, determining who is admitted to (full) membership, and engaging in diaspora policies.

Transnational spaces provide alternative definitions of units of analysis that are general enough to think of social entities as de-territorialized and territorialized at the same time. By appropriately defining our units of analysis relative to our respective problematic, we avoid the tendency toward bounded static thinking. Units of analysis need to be chosen according to the question at hand and the level(s) analyzed: household, networks, organizations, states, etc. Thus, instead of starting off with the national state and the system of national states or with a borderless world of networks, it may be more fruitful to use concepts such as social space to delineate the social formations relevant for the subject areas. To put it briefly: there is no privileged unit or site of analysis from a transnational optic. A transnational methodology has to consider both deterritorialized elements in the form of intense flows across the borders of states and territorial elements in the efforts of states and organizations to control such flows and establish criteria of membership for persons. An appropriate starting point is therefore the concept of transnational social space which includes both a "space of flows" and a "space of places"; the former referring to the deterritorialized and the latter to the territorial elements.

\section{The Challenge of Essentialism}

Migration scholars often use an ethnic and a national lens to conceptualize migration and settlement processes. We find such assumptions in theories of assimilation as well as in incorporation approaches. To be more precise, the starting point of this type 
of research is not geographic mobility, social networks or decision making, but how a particular ethnic or national group integrates or is incorporated into a national polity. Such an approach can also be found in studies on transnational practices. Consequently, qualitative studies which dominate transnationally-oriented research select interview partners according to their ethnicity or national belonging. In short, methods of data analysis or data interpretation are characterized by an ethnic lens because ethnic and national categories are used as the main variables to explore research outcomes. Yet it would be misleading to reject outright the use of ethnic and national categories as a way to enter the field. Instead, it is necessary to reflect upon their use, and also to use alternative categories, if appropriate and possible.

Categories such as 'migrant,' or 'non-migrant,' 'Mexican' or 'American,' 'labour migrant' or 'refugee' are frequently used as central criteria in research designs with no regard to either the ways in which these categories are formed by scientific and non-scientific discourses or the conditions under which they are relevant for the social practices of mobile and non-mobile people (Glick Schiller, Çağlar and Guldbrandsen, 2006). One way to deal with essentialism is to build procedures of self-reflection into the design of the empirical study. So far, however, very few researchers have done so.

The use of an ethnic lens within the organization of empirical research is sometimes accompanied by naturalizing views on ethnicity. By defining ethnicity and nation as naturally given entities resulting from common cultural scripts, researchers consider neither the constructionist quality of 'group formation', nor the processes by which ethnic and national categories are socially developed, distributed, and applied. This trap of 'groupism' (Brubaker, 2002) is especially relevant in the study of so-called diasporic and transnational communities. Researchers fall into this trap if they do not probe into how such communities are socially constituted relationally in processes of interaction with other groups, and in looking at the consequences of the usage of terms such as diaspora in public debates. In committing this mistake, researchers accept that such communities are stable over time, and of overriding importance for the individual identities and social practices of their members. Researchers then do not consider that markers of difference other than ethnicity and nationality - such as transnationality, gender, class, religion or even life-style - may be equally or even more important than ethnicity or nationality to group members. If researchers are not aware of the tendency toward groupism they may easily fall prey to nationalist propaganda by both diasporas and governments. The two challenges of methodological nationalism and group essentialism are closely related. Without overcoming groupism we would simply replace nationalism with transnationalism - one-ism with another.

Under conditions of transnationalization, persons may hold multiple memberships in different social spheres with which they affiliate themselves. To be more precise, persons are able to hold different ethnic, national or religious affiliations simultaneously. This may even extend into the legal sphere. Take the example of multiple citizenship: there are more and more persons around the globe who hold citizenship in more than one state. And, correspondingly, an increasing number of states have become more tolerant in not requiring a renunciation clause (Faist and Kivisto, 2008). This way of thinking about multiple attachments, memberships and roles is not novel, but rather involves the applica- 
tion of a fundamental sociological insight that persons may engage in various, sometimes even conflicting social roles. Transnational methodology simply adds the perspective that such roles and belongings can extend across the borders of states - quite plausibly so, because societies are not bound by the territorial reach of states. In general, this way of thinking considers a both/and logic of multiple memberships to delineate units of analysis.

This self-reflexive turn stimulates strategies of empirical studies such as de-ethnicization (Fenton, 2011), which build on constructivist and process understandings of ethnicity (Barth, 1969). Heterogeneities other than ethnic or national belonging may be relevant for answering specific questions. In each instance it is necessary to pose the question: 'what is it a case of? In other words, the significance of heterogeneities is determined by the question asked and should not peremptorily focus on ethnicity just because we are dealing with migrants. For example, researchers can begin by focusing on other heterogeneities, such as religion, as an entry point (Glick Schiller et al., 2005).

\section{The Challenge of Positionality}

To an increasing degree, scholars who conduct empirical research on transnationalization have been addressing the problem of the essentializing view of ethnicity by including self-reflection on the researcher's position in the research process. Positionality here does not refer to the politicized or ethnicized position of the researcher. Instead it connotes the theories and methods that researchers apply in devising and carrying out research on transnationalization. Positionality is not a fixed and immutable position which is set at the beginning and remains unchanged. Rather, it is a process. In the course of doing research researchers may adapt and modify the theories used and the methodological position taken.

Positionality concerns the power asymmetries in transnationally composed research teams. In other words, the challenge concerns the position of the researcher vis-à-vis the research subjects, and the relationships of the researchers to one another in transnationally composed research teams. One may look at the boundary construction around identification, such as 'researcher' versus 'worker' in an interview situation. There is usually a power hierarchy involving the researcher's positionality from the optic of heterogeneities such as class, gender and transnationality. Such hierarchies emerge in situations in which the two parties define their interactions by using terms along various heterogeneities and assign each other more or less powerful social positions. As ethnographic research has long recognized, such hierarchies are not always clear-cut. While some authors have argued that the researchers mainly have the power of definitions over the researched because they have the power to select empirical observations, questions, and results, the power relationship within the research process may be relational and changeable (Coffey, 1996).

A prominent type of transnational studies, multi-sited research, entails not only inquiries in various sites in different countries but often also calls for the collaboration of researchers from the places in which the research is carried out. This challenge gives rise to some well known problems. For example, collaboration can sometimes lead to the mutual ethnicization of the collaborating researchers. While the funds come from 
countries in the North and West, researchers in the East and South are often relegated to carry out research designed by the former. Also, it is more likely that researchers from the former countries are able to write articles and build a career on this research. In short, the resource and, more generally, the power asymmetries between North and West on the one hand, and South and East on the other hand, are also reflected in the design, conceptualization, operationalization, implementation and interpretation of empirical research across borders. The researchers concerned and the research institutions involved are also part of the respective transnational social space in which and upon which they have chosen to conduct research.

The inherently multi-disciplinary transnational perspective, accompanied by reflections on power and resource asymmetries innate to transnational social spaces, helps us to take up and extend the challenges posed to early migration research in the first two decades of the twentieth century. A fitting historical example is the masterpiece The Polish Peasant in Europe and America by William Thomas and Florian Znaniecki (orig. 19181920). The authors devised concepts such as "super-territorial organization" (Vol. 5) in order to deal with the role of migrant organizations in the US and their cross-border links back to Poland. In the present day, the quantity and quality of transnational linkages and associations may have increased not only in this but in other cases. What has remained constant is the pre-occupation of social scientists with issues of integration and incorporation. Yet this concern can no longer be separated from transnational linkages - the latter are integral parts of any effort to account for social (in)equalities arising out of migratory processes. In fact, Thomas and Znaniecki can already be considered a transnational research team. Both spent considerable time in Europe conducting field research, in addition to the work carried out in Chicago: Florian Znaniecki collected data in Poland but William Thomas himself also conducted research in Europe on and off for about ten years. Today research projects often go well beyond the cooperation between two researchers and we must therefore think carefully about the prerequisites for collaboration in bigger research teams.

\section{METHODS TO ADDRESS METHODOLOGICAL NATIONALISM, ESSENTIALISM AND POSITIONING OF RESEARCHERS}

Transnational methodology is evolving to address the distinct challenges of methodological nationalism, essentialism and positioning of researchers in transnational social spaces. Innovations in methods are necessary, and we are in the midst of an ongoing debate on how best to achieve them. While criticism of established methodologies is by now widespread, ways to overcome the challenges have not yet been agreed upon. Nonetheless, research is ongoing and even in the absence of clear-cut transnational methodologies methods need to be devised in order to put to use the insights of a transnational optic. The methods have to be up to the task of solving the puzzles. One important caveat is in order. Research on transnationalization, transnational social spaces and transnationality need not necessarily be multi-sited. Researchers may capture important aspects by focusing on a single site. Yet in order to understand transnationality in cross-border social spaces more comprehensively as emerging social formations, multi-sited methods are helpful. 
To illustrate how the research question itself can guide the selection of the method we refer again to The Polish Peasant. The methodology the authors used clearly depended on the question they and in particular William Thomas posed, namely how social 'disorganization', which was caused by modernization, could lead to a reorganization of the social order. He was occupied with how people were exposed to social change, and how this change was reflected in migration and settlement, both in Poland and the US. While he took account of transnational ties and practices, Thomas was nevertheless bound to the image of migrants as being 'uprooted'. To study the repercussions of what he perceived to be social disorganization, Thomas certainly could not rely on classical ethnographic methods, such as participant observation. While walking the streets of Chicago and pondering the problem, so the story goes, he was quite by accident nearly hit by a garbage bag - and out fell a letter written by a Polish peasant to a relative in Chicago. Subsequently, Thomas hit upon the analysis of letters to develop what later became biographical methods in sociology. The main point here is that there is thus an elective affinity between theories and concepts, the main questions asked, methodology and methods used on the ground.

Today, nearly a hundred years later, we have a wide array of different methods available to research cross-border practices and social spaces. We also have adaptations of ethnographic, network and survey research to capture cross-border processes and institutions; in addition, as appropriate, we can make use of multi-sited methods, employing online and offline research, as well as mobile and stationary research. These methodological contributions come from very different disciplinary traditions and cover almost all facets of empirical social research. The fields of geography and anthropology have provided the multi-sitedness approach, as evidenced in multi-sited ethnography (Marcus, 1995) but also simultaneous matched sample methodology (SMS), which includes network analysis as well (Mazzucato, 2008). Research on mobilitiy - understanding spatial movements other than migration, has engaged in mobile ethnography (Urry, 2007) where the focus is on the process of movement itself. Often network methods figure prominently in online/ internet research derived from communication studies. Here, the virtual networks of migrants and their significant others stand at the centre of attention, sometimes coupled with non-virtual social and symbolic ties. Last, there are various survey methods which are prominent, among others, in political science and sociology. Most of these studies are cross-sectional. In order to trace the evolution and reproduction of cross-border practices in social spaces it is necessary to engage in panel studies - a window for future research.

Some survey researchers already use mixed methods, linking qualitative and quantitative methods. Nonetheless, we need to consider that there are two different logics of research, exemplified by the two types of methods. Quantitative, which often employs statistical methods, seeks to estimate the effects of variables on various levels (persons, countries, etc.). For example, researchers may ask what effects transnationality of migrants and their associated households (as a marker of heterogeneity) may have on the educational opportunities of children. The researcher collects data on a range of different variables - above all transnationality (e.g. visits, stays abroad, exchange of goods and information) but also educational background and professional position of parents, frequency of shifts from one educational system to another, etc. - and then estimates how much of the variance is accounted for by the different variables identified. In essence, quantitatively oriented research measures the average effects of variables. By contrast, the 
aim of qualitative approaches is to ask questions about the properties of a case and seek to account for the particular outcomes in a particular case. In the example just used the interest would be, for instance, in how the shifting of children from one country to another in the case of parents with comparable socio-economic background may be different. The researcher might wish to understand how, for example, the second-generation children of Greek and Turkish migrant parents in Germany with similar socio-economic characteristics (e.g. highest degree achieved) differ with respect to their educational success, or how the educational success of the same migrant category may differ across countries, and whether transnational ties and child-shifting play any role in this differential outcome. Instead of only identifying which variables account for the difference, research in a qualitative logic asks: In which way have processes led to the differential outcomes observed? It is important to emphasize that research in both quantitative and qualitative realms may seek to account for mechanisms which lead from an initial condition - in this case similar socio-economic background of parents and social practices of child shifting across borders (e.g. children may not live with their parents abroad but with other relatives in the place of origin) - to different outcomes - in this case differences in educational success. So while mixed methods occupy an increasingly prominent role especially in survey studies, we should be aware that the logics themselves cannot be mixed. The mixing refers to the fact that the qualitative and quantitative methods complement each other.

\section{Multi-sited Ethnography and Mobile Ethnography}

One of the earliest and most widespread forms of research into transnational formations is ethnography in various sites of the borders of states. The starting point with this method is identifying the actual empirical field by tracing the practices and connections across borders in addition to specifying contexts of research and units of analysis. Instead of looking at social life in a 'container', multi-sited ethnography is interested in the extension of social and symbolic ties across various sites. While earlier theories situated their case studies within a world system and compared sites within that framework, multisited ethnography starts from the assumption that the world system is embedded in the sites analyzed. The basic principle of multi-sited ethnography, as suggested by Marcus (1995), who summarized a spade of proposals, is to 'follow' the movement of actors, objects, cultural scripts and artefacts. The ethnographer moves through a spatially diverse and dispersed field via sojourns in two or more places. This involves constructing the empirical field by indicating various geographic localities. To be more precise, it enables the organization of research designs, methods of data collection and data interpretation. Scholars make increasing use of multi-sited ethnography, not only because it justifies simultaneous research in different geographic localities and social sites, but because it also provides insights into the complexity of transnational phenomena (Falzon, 2009). The suitability of multi-sited ethnography for migration research results from understanding 'sites' of an empirical field both as territorial and social or cultural entities by following peoples and artefacts. The growing popularity of multi-sited ethnography can also be explained by pragmatic reasons. There has been a tendency toward shorter stays in the field, shorter stays in various sites - and, in order to gain depth, repeated short-term stints in the same sites. Multi-sited ethnography is also appealing for conceptual reasons. It 
does not, as world theories do, rely on a strong theoretical orientation to guide empirical research. Rather, the ethnographer develops a framework in the context of field research.

An example of this methodological approach is Cindy Horst's study of refugees from Somalia in refugee camps in Northeast Kenya. She explicitly introduces a transnational perspective to the study of refugees in pursuing an approach she calls "dialogical knowledge creation" (2006: 27). According to Horst, research methods have to "involve dialogue between refugees, agencies and academics; leading to an exchange and discussion of ideas, concepts and theories." (2006: 25) Knowledge creation involved participatory approaches that actively engaged Somali refugees, policy makers and practitioners in both data collection and analysis, for example, by discussing her research questions and methods with refugees and by sharing interview reports, fieldwork reports and later articles and preliminary chapters. The dialogue continued after Horst left the camps. She contacted refugees living in Western countries, published articles on diaspora websites and solicited feedback and suggestions. She also sent her findings to the UN and received responses from policy makers, UN or NGO staff and researchers. The research had a notable transnational dimension in another respect. Horst emphasizes that "(i)n order to understand their responses to camp life, it is of great importance to examine their ways of coping with various insecurities in Somalia before the war" (2006: 201), that is, the Somali nomadic heritage which implied strong reciprocities and solidarities in networks. This heritage entailed, for example, the obligation to assist one another in surviving. Interestingly, this heritage has also changed, becoming largely transnational in kind. The links that Somalis maintain with relatives outside the camps are essential for their daily survival. These links reach relatives throughout the larger cross-border diaspora. The transnational channels of the diaspora included the "taar" (radio communication transmitters), telephone, sending of messages and goods via those travelling to a place where relatives live and "xawilaad", an informal value-transfer system, which enables both communication and the sending of remittances. In sum, Horst adapts her research methods to analyze Somali refugees in the camps as a transnational community. This community, even before flight, was "a nomadic people". Mobility across borders has always been an essential part of their livelihoods and identities, as the Somali have not had a proper nation state and some authors even argue that they never had one. Horst speaks of a "diaspora mentality" (2006: 34) which brought advantages for Somalis in Dadaab and which fosters an extensive transnational network of relatives, allowing them to live in relative prosperity.

The specific value of multi-sited ethnography as one of the most widespread methods for transnational research emerges in comparison with another approach which also seeks to find out how sites connect to each other - namely "global ethnography", building on the extended case study method developed in anthropology and adapted by sociological researchers (Burawoy et al., 2000). The differences between these two approaches can be seen in three major respects. First, multi-sited ethnography focuses on sites in various countries whereas the main concern of global ethnography is the different scales of analysis; in other words, global ethnography is concerned with how the local and the global interact. For example, one of the central concerns of global ethnography is how global discourses on human rights are adopted and adapted by local social movements. Second, the two approaches differ in their understanding of context. In multi-sited ethnography the context evolves out of the researcher's own discovering and delineating her 
field. In global ethnography the overall context is largely pre-defined by concepts that are important to existing theories; for example in world system theories this would be capitalism. Third, the role of theory in the construction of the research design differs in a significant way: theoretical constructs are held in abeyance in multi-sited ethnography but play a crucial role in global ethnography.

Mobile ethnography is a method of more recent vintage in which the correspondence between the mobility of persons and the methods of researchers is placed at the fore. It addresses directly the spatial movement of people in transnational social spaces through direct observation of the associated social practices, such as sending remittances or organizing in associations. This approach begins with mobilities and patterns of geographical movements, not with groups, potentially averting the essentialism identified above by avoiding an exclusive focus on migrants solely as ethnic or national groups. Mobile ethnography has been inspired by multi-sited ethnography and offers insights 'into a multitude of mobile, material, embodied practices of making distinctions, relations and places' (Büscher et al., 2010: 105). This strategy recommends collecting data by 'observing people's mobility', 'walking with', 'stalking' or 'lurking' around others. A mobile ethnography approach enables researchers to define geographic and virtual mobility as an empirical field. According to this position, scholars dealing with transnational practices would need to go beyond state responses to mobility and also look at practices of (potential) migrants which may result in both mobility and immobility.

\section{Multi-sited Matched Samples}

One of the most systematic extensions of multi-sited research is the method of matched sampling, the so-called Simultaneous Matched Sampling Method (Mazzucato, 2008). The method is based on one of the main ideas of the transnational approach, namely the possibility of simultaneity - the overlapping or plurality of ties reaching into more than one site, in this case multiple sites in more than one country. The method thus considers the simultaneity of the transnational practices of individuals and groups taking place in multiple - national and non-national - localities. The focus is on transactions involving communication and the movement of goods and on the networks of those who have migrated and those who have stayed in place or remained behind. Mazzucato and her colleagues used (non-representative) snowball sampling among migrants from Ghana in Amsterdam and traced their transactions back to two sites in the emigration state, in the capital Accra and in rural villages and towns in a region in the north of Ghana around Kumasi. Working with over 100 Ghanaian migrants in Amsterdam the researchers came up with 29 networks. They recorded all transactions on a monthly basis conducted in 8 domains (housing, business, funerals, church, health care, education, communication and community development projects) for a year in 2003 and 2004. The researchers thus worked in sites in both the Netherlands and Ghana, and communicated quasi-simultaneously about the linkages between their respective parties. In this way this method could overcome one of the limitations of multi-sited research - the fact that individual researchers usually cannot capture the simultaneity of transactions. Of critical importance is the fact that this method allows for tracing two-way flows between transnational sites; for example, 'reverse remittances' from Ghana to the Netherlands which are used for the 
legalization of undocumented migrants, financial remittances from Amsterdam to Kumasi or Accra or finding a marriage partner, among other purposes. A specific focus was on the impact of migrant linkages on their home country's institutions via rules, values and norms that shape the economies of both their place of residence and their home communities. For example, transnational practices around funerals led to institutional change, according to the researchers; they found that funerals were one of the main reasons migrants remain engaged with their home communities and continued to send remittances there. Migrants invested in funerals to demonstrate that they help the family/the community and to reestablish and to legitimize their position within the family and the home community despite the geographical distance. Migrants were the main financers of funerals (often having to borrow money from their network members based in the Netherlands). In turn, these practices yielded positive economic effects in the home community. For example, villagers and bars hosted and fed funeral guests.

\section{Virtual Networks}

To uncover organizational structures and orientations of migrants' political online activities, Kissau and Hunger (2010) chose the Internet as a research site. The challenges for research are formidable because the Internet is a dynamic construct whose content, pages and user profiles may change daily. Nonetheless, as the Internet enables communication between members of a group dispersed across national state borders, a website analysis can yield valuable insights into communication networks. The researchers made a structured website search with the help of search engines and the snowballing method, and came up with about 800 websites for the three groups under analysis - three immigrant categories in Germany, Turks, Kurds and Russians. In order to capture this moving target, they drew on a variety of research methods, out of which three proved to be most important. First, they conducted an analysis of the link structure of these websites, using hyperlink analysis to uncover virtual networks. Second, they surveyed the sites' users and operators to detect individual interests and practices beyond the collective representations presented on the websites. Third, they selected about 30 websites for a detailed content analysis of pages created and used by migrants for political activities. Here the researchers looked at characteristics such as the thematic orientation, the self-description and group boundaries. This virtual network methodology helped the researchers to classify the type of Internet community, to acquire insights into the internal interaction of migrants within the respective online communities and to look at strategies of communication between these groups and their political environment. The researchers' methodological caveat needs to be taken seriously: Kissau and Hunger add that online analysis does not replace fieldwork. After all, online and offline worlds interact, and are not independent of one another.

\section{Surveying Transnationality}

The qualitative methods discussed so far serve to identify the phenomenon of transnational ties, practices and cross-border social spaces. They are also instrumental in advancing our understanding of the mechanisms relevant in (re)producing practices and spaces. In order to establish the prevalence and extent of transnational ties, practices and spaces and identify the major factors associated with their emergence, it is now time to 
turn to quantitative methods because studies based on qualitative methods often have the limitation that they examine transnationality among migrants who entertain cross-border ties without including a reference group. This drawback echoes a more general criticism of studies on transnationalism: "They study cases of the phenomenon itself so it is difficult to say anything about the extent of the phenomenon and whether it is increasing." (Portes, 2001: 182-183) There is usually no comparison group in such studies of persons who did not migrate or who returned from the immigration to the emigration country. This is a result of what has been called "sampling on the dependent variable", that is migrants with transnational ties are not compared with suitable comparison groups, namely those without cross-border links. Therefore, while qualitative studies were able to document the existence of transnational phenomena, we have little knowledge on its numerical prevalence. Also, and this is another crucial aspect not addressed by most existing studies, there is little evidence regarding the temporal dimension, both in historical perspective and across individual and family life courses.

One of the most extensive surveys of transnational practices among migrants has been the Comparative Immigrant Entrepreneurship Project (CIEP, Portes, 2003). Through quantitative fieldwork, supplemented by qualitative methods, this project focuses primarily on establishing the extent of transnational practices. The fieldwork was conducted between 1996 and 1998 among the following groups: Colombian, Dominican and Salvadoran immigrants. These categories represented, jointly, over one-fifth of Latin American immigrants in the US at the time. The contexts of exit and reception of these groups were quite distinct. CIEP proceeded in two phases. Phase 1 comprised interviews with 353 key informants in six areas of immigrant concentration in the United States, two for each selected group, and in six foreign cities, including capitals of each selected country of origin. Phase 2 consisted of a survey of the three immigrant groups in their principal areas of concentration in the United States, and proceeded in two stages. Stage 1 was a multi-level random sample based on city blocks as the primary sampling units, and a systematic random sample of household heads from the selected nationalities in each block. Stage 2 was a referral sample, based on data gathered from informants in the first phase and conducted through multiple snowball chains, aimed at identifying immigrants involved in entrepreneurial activities in general and transnational activities in particular. Note that the snowball procedure ensured a sufficient number of transnational entrepreneurs for quantitative analysis but (on purpose) biased the sample in their direction.

With this design, Portes and his collaborators could gauge quantitatively the spread and extent of transnational activities in the economic, political and socio-cultural spheres. The share of transnationals did not exceed one-fifth within each group across the three realms of activities and transnational social integration was not the dominant mode of adaptation of these immigrant groups. Nonetheless, transnational practices were quite substantive among certain subcategories - e.g. the self-employed and the politically active. Thus, though it turned out that transnationally active migrants - defined as those who entertained dense and continuous ties across borders - were in a minority, the phenomenon as such could be established with great vigour and certainty. This kind of survey acts as a corrective to ethnographic studies that sometimes make it appear as if, for example, transnational entrepreneurship had become the main form of economic adaptation among contemporary immigrants. CIEP is an example of a cross-sectional study with 
data from specific points in time. Yet only longitudinal studies allow for results which establish a historical trajectory of the phenomena observed.

The ethnosurvey methodology which combines in-depth anthropological work with large-scale surveys is of crucial importance for transnational methodology, although the original idea was not to match persons in emigration with those in immigration countries on a large-scale level. While the Mexican Migration Project (MMP) was not designed to focus on transnationality, its elements are helpful for the further development of transnational methodology. MMP has used a so-called ethnosurvey to trace migration patterns across time between Mexico and the US. Douglas Massey, Jorge Durand and their colleagues developed the ethnosurvey as an alternative methodology to the customary immigration surveys which have "serious inadequacies with respect to measuring undocumented migration" (Durand and Massey, 2006: 321). The ethnosurvey is a multi-method data-gathering technique that simultaneously applies ethnographic and survey methods within a single study. Two qualitative components, namely ethnographic case studies in the selected communities and in-depth interviews, are combined with a semi-structured quantitative survey that is based on a combination of random and non-random sampling procedures. The combination of quantitative and qualitative methods corresponds to what is now called a mixed methods design and proceeds as follows: First, the researchers select a site and start with conventional ethnographic fieldwork, including participant observation, unstructured in-depth interviewing and archival work. Data from this initial phase are then available for designing the survey instrument. The survey is administered to a probability sample of respondents selected according to a carefully designed sampling plan (Durand and Massey, 2006: chapter 13). During the survey qualitative fieldwork continues, or resumes after the survey's completion. Ideally, the flow of analysis is organized so as to make preliminary quantitative data from the survey available to ethnographic investigators before they leave the field, allowing patterns emerging from quantitative analysis to shape qualitative fieldwork, just as insights from early ethnographies guide later statistical studies.

Originally the researchers surveyed four communities in Mexico. To date the MMP has surveyed 81 Mexican communities and US settlements. The data gathered include complete histories of migration, work and border crossings for all household heads and spouses; basic information on the first and most recent US trips of all household members with migratory experience; and detailed information about experiences on the most recent international trip made by the household head. So far, the MMP has surveyed 81 two-national communities and yielded data on nearly 18000 current and former US migrants. Although the data are of "limited generalizability" and are not representative of Mexico or Mexican immigrants in general, they are useful for portraying and analyzing aggregate trends.

The two surveys discussed and studies-in-progress such as the German-Turkish Panel Study (Faist et al., 2011) constitute significant steps forward on at least three fronts. First, normally we have only national data for social ties and practices that cross nation-state boundaries. There is a deeper epistemological problem already alluded to: the evolution of survey research has been closely linked to the development of nation-states and thus also the needs of states. Second, many of the existing studies tend to presume 
the sedentary nature of the researched population. Therefore, most cross-country (internationally) comparative samples, such as the European Labour Force Surveys (ELFS), are known to under-sample along certain categories of activities. For example, ELFS does not cover mobile categories of persons, such as seasonal migrants or undocumented workers (for example, in domestic and care services) because persons not covered in the destination country will not necessarily be covered in the country of origin. Third, both CIEP and the ethnosurvey include elements of qualitative research even though their logic is quantitative. They thus implement mixed methods designs. Qualitative methods are important because they are indispensable to determine reasons for coverage errors and the effects of different sampling strategies. Moreover, in both surveys interviews were not simply carried out with the help of standardized questionnaires but included intensive conversations between interviewers and respondents to collect information perhaps missed by the standard questionnaire (e.g. patterns of mobility of household members, etc.). In essence, we need ways to capture the continuous multi-directional mobility of labour migrants between states and regions and approaches that contextualize migration within a plurilocal spatial framework.

\section{OUTLOOK}

The methodology of cross-border analysis needs to be distinguishable from comparative research that focuses on entities such as national states as relatively exclusive and bounded units of analysis. One of the most promising solutions has been multi-sited ethnography that is, carrying out research in the sites of agents' practices in various countries. Multi-sited research in its various expressions is built on the idea of letting go of homogenizing notions of society and nation, culture and ethnicity. As we have seen, the challenges of capturing simultaneity through other multi-sited research methods are tremendous but manageable. The preceding discussion has presented additional methods appropriate to transnationally informed methodology, such as online analysis or a mixedmethod application of representative survey research. It stands to reason that more work is needed to systematically develop various forms of multi-sited research. What all methods have in common, however, is an agency-oriented, processual view of cross-border social phenomena. 


\section{References}

AMELINA Anna, FAIST Thomas, NERGIZ Devrimsel and GLICK SCHILLER Nina (Eds.) (2012a) Beyond Methodological Nationalism: Social Science Research Methodologies in Transition, London, Routledge (forthcoming).

AMELINA Anna, FAIST Thomas, NERGIZ Devrimsel and RESCHER Gilberto (Eds.) (2012b) De-naturalizing nation states in research methodologies: key concepts of transnational studies in migration, Ethnic and Racial Studies (forthcoming).

BARTH Frederik (1969) Ethnic Groups and Boundaries: The Social Organization of Cultural Difference, Oslo, Universitetsforlaget $153 \mathrm{p}$.

BONIFAZI Corrado, OKOLSKI Marek, SCHOORL Jeanette and SIMON Patrick (Eds.) (2008) International Migration in Europe. New Trends and New Methods of Analysis, Amsterdam, Amsterdam University Press, 342 p.

BRUBAKER Rogers (2002) Ethnicity without Groups, Cambridge, MA, Harvard University Press, $130 \mathrm{p}$.

BURAWOY Michael, BLAU Joseph A., GEORGE Sheba, GILLE Zsuzsa, THAYER Millie, GOWAN Teresa, HANEY Lynne, KLAWITER Maren, LOPEZ Steve H. and RIAIN Sean (2000) Global Ethnography: Forces, Connections and Imaginations in a Post-Modern World, Berkeley, CA, University of California Press, $210 \mathrm{p}$.

BÜSCHER Monika, URRY John and WITCHGER Katian (2010) Mobile Methods, London, Routledge, $223 \mathrm{p}$.

CASTELLS Manuel (1996) The Rise of the Network Society. The Information Age: Economy, Society and Culture Vol. I., Oxford, Blackwell, $656 \mathrm{p}$.

COFFEY Amanda (1996) The Power of Accounts: Authority and Authorship in Ethnography, International Journal of Qualitative Studies in Education, 9 (1), pp. 61-74.

DURAND Jorge and MASSEY Douglas (Eds.) (2006) Crossing the border: Research from the Mexican Migration Project, New York, Russell Sage Foundation, 384 p.

FAIST Thomas (2011) Academic knowledge, policy, and the public role of social scientists, in Thomas Faist, Margit Fauser and Peter Kivisto Eds., The Migration-Development Nexus: Transnational Perspectives, Houndmills, UK, Palgrave Macmillan, pp. 185-203.

FAIST Thomas (2004a) The border-crossing expansion of social space: concepts, questions and topics, in Thomas Faist and Eyüp Özveren Eds., Transnational Social Spaces: Agents, Networks and Institutions, Aldershot, UK, Ashgate, pp. 1-36.

FAIST Thomas (2004b) Towards a political sociology of transnationalism, European Journal of Sociology, 45 (2), pp. 331-366.

FAIST Thomas and ETTE Andreas (2007) Between Autonomy and the European Union: The Europeanization of National Immigration Policies, Houndmills, UK, Palgrave Macmillan, $288 \mathrm{p}$.

FAIST Thomas and KIVISTO Peter (2008) Dual Citizenship in a Globalizing World: From Unitary to Multiple Membership, Houndmills, UK, Palgrave Macmillan.

FAIST Thomas, FAUSER Margit and REISENAUER Eveline (2012) The Transnational in Migration, Cambridge, Polity Press (forthcoming).

FAIST Thomas, FAUSER Margit and REISENAUER Eveline (2011) Perspektiven der Migrationsforschung: Vom Transnationalismus zur Transnationalität, Soziale Welt, 62 (2), pp. 203-220.

FALZON Marc-Anthony (2009) Multi-Sited Ethnography: Theory, Praxis and Locality in Contemporary Research, Aldershot, UK, Ashgate, 208 p.

FENTON Steve (2011) The global comparative analysis of ethnic conflicts, International Journal of Comparative Sociology, 45 (1), pp. 67-82. 
GLICK SCHILLER Nina, ÇAĞLAR Ayşe and GULBRANDSEN Thaddeus C. (2006) Beyond the ethnic lens: locality, globality and born-again incorporation, American Ethnologist, 33 (4), pp. 612-633.

GLICK SCHILLER Nina, NIESWAND Boris, DARIEVA Tsypylma, YALCIN-HECKMANN Lale and FOSZTÓ László (2005) Pathways of Migrant Incorporation in Germany, Transit, 1 [en ligne]. URL: http://repositories.cdlib.org/ucbgerman/transit/vol1/iss1/art50911

GORDON Milton M. (1964) Assimilation in American Life: The Role of Race, Religion and National Origin, New York, Oxford University Press, 286 p.

HELD David, MCGREW Andrew, GOLDBLATT David and PERRATON John (1999) Global Transformations: Politics, Economics and Culture, Stanford, CA, Stanford University Press, $544 \mathrm{p}$.

HORST Cindy (2006) Transnational Nomads: How Somalis Cope with Refugee Life in the Dadaab Camps of Kenya, Oxford, Berghahn Books, 252 p.

KISSAU Karin and HUNGER Uwe (2010) The internet as a means of studying transnationalism and diaspora, in Rainer Bauböck and Thomas Faist Eds., Diaspora and Transnationalism: Concepts, Theories and Methodology, Amsterdam, Amsterdam University Press, pp. 245-266.

MARCUS George (1995) Ethnography in/of world system: the emergence of multi-sited ethnography, Annual Review of Anthropology, 24, pp. 95-117.

MARTINS Herminius (1974) Time and Theory in Sociology, in John Rex Ed., Approaches to Sociology: An Introduction to Major Trends in British Sociology, London, Routledge \& Kegan Paul, pp. 246-294.

MASSEY Doreen (2008) For Space, London, Sage, 232 p.

MAZZUCATO Valentina (2008) Simultaneity and networks in transnational migration: lessons learned from a simultaneous matched sample methodology, in Josh DeWind and Jennifer Holdaway Eds, Migration and Development Within and Across Borders: Research and Policy Perspectives on Internal and International Migration, Geneva, International Organization for Migration (IOM), pp. 69-100.

PORTES Alejandro (2003) Conclusion: Theoretical Convergences and Empirical Evidence in the Study of Immigrant Transnationalism, International Migration Review, 37 (4), pp. 874-892.

PORTES Alejandro (2001) Introduction: the debates and significance of immigrant transnationalism, Global Networks, 1 (1), pp. 181-193.

SINGLETON Ann (1999) Combining Quantitative and Qualitative Research Methods in the Study of International Migration, International Journal of Social Research Methodology, 2 (2), pp. 151-157.

THOMAS William I. and ZNANIECKI Florian (1918-1920) The Polish Peasant in Europe and America, 5 Vol., Chicago, University of Chicago Press (Vol. 1-2), Boston, Richard G. Badger (Vol. 3-5).

WALLERSTEIN Immanuel (1974) The Modern World-System, New York, Academic Press, 256 p.

WIMMER Andreas and GLICK SCHILLER Nina (2003) Methodological nationalism: the social sciences and the study of migration: an essay in historical epistemology, International Migration Review, 37 (4), pp. 576-610.

URRY John (2007) Mobilities, Cambridge, Polity Press, 336 p. 


\title{
Toward a Transnational Methodology: Methods to Address Methodological Nationalism, Essentialism, and Positionality
}

\author{
Thomas Faist
}

\begin{abstract}
A transnational perspective on cross-border migration and its consequences extends beyond the immigration countries and encompasses regions of origin and destination, and other places which are criss-crossed by the connectivities of persons, groups and organizations. Based on the wide range of knowledge generated by transnational studies in the field of migration this article explores how these empirical results were generated. A transnational methodology needs to address three challenges: methodological nationalism, group essentialism, and the positionality of researchers. This task necessitates, first, the presentation of a methodological toolbox for studying transnational phenomena empirically, that is, transnationality but also the transnational social spaces. In doing so, this article engages in reflections on how to conduct research and assess evidence. This endeavour also includes discussion of how relevant research techniques are applied, using selected examples.
\end{abstract}

\section{Vers une méthodologie transnationale : méthodes pour aborder le nationalisme méthodologique, l'essentialisme et le positionnement}

Thomas Faist

Une perspective transnationale sur la migration transfrontière englobe les pays d'immigration et s'étend aux régions d'origine et de destination ainsi qu'aux autres lieux où s'entrecroisent les échanges de personnes, de groupes et d'organisations. Basé sur le large éventail de savoirs produit par les études transnationales dans le champ des migrations, cet article explore la manière dont ces résultats empiriques ont été générés. Une méthode transnationale a trois défis à relever : le nationalisme méthodologique, l'essentialisme et le positionnement des chercheurs. Cette tâche nécessite d'abord la présentation d'un ensemble d'outils méthodologiques pour étudier empiriquement les phénomènes transnationaux, c'est-à-dire la transnationalité, mais aussi les espaces sociaux transnationaux. En faisant ainsi, cet article engage des réflexions sur la manière de conduire la recherche et d'évaluer le résultat. Cette tentative inclut aussi une discussion sur la manière dont les techniques pertinentes de recherche sont appliquées à partir d'exemples choisis. 


\title{
Hacia un método transnacional: métodos para abordar el nacionalismo metodológico, la esencialidad del objeto y el posicionamiento del investigador
}

\author{
Thomas Faist
}

Una perspectiva transnacional sobre la migración transfronteriza y sus consecuencias va mas allá que los países de emigración y se extiende también a las regiones de origen y de destinación así como a otros lugares en donde se producen los intercambios entre personas, grupos y organizaciones. Basado en la amplia gama de conocimientos generados por los estudios en el campo de las migraciones transnacionales, este artículo explora cómo se generan estos resultados empíricos. Un método transnacional supone tres desafíos: el nacionalismo metodológico, la esencialidad del objeto y el posicionamiento del investigador. Esta tarea necesita principalmente herramientas metodológicas para estudiar los fenómenos empíricos es decir lo transnacional y los espacios sociales transnacionales. Procediendo de esta manera, este artículo aborda reflexiones sobre la manera de llevar a cabo la investigación y de evaluar los resultados. Esta tentativa incluye también una discusión sobre la forma como son aplicadas las técnicas pertinentes de investigación a partir de ejemplos seleccionados. 